\title{
The Effectiveness of Physiotberapy During the Comrades Ultramarathon
}

\author{
LINDA EXELBY
}

\section{SUMMARY}

Physiotherapy stations along the Comrades Marathon route provided treatment for musculoskeletal problems. Common muscular conditions encountered were fatigue, cramp and strains. These were treated with ice massage, conventional massage or a combination of the two. Every runner was also encouraged to stretch the affected muscles. Joint related injuries were strapped. Questionnaires were sent to runners to assess the effectiveness of the treatment received. Most runners reported that the treatments helped. In spite of the limited treatment time available nearly half of those treated gained lasting relief.

\section{INTRODUCTION}

One of Natal's main annual events, for both spectators and runners is the Comrades Marathon - a 90 kilometre race run over hilly terrain. The leaders spend approximately $5 \frac{1}{2}$ hours on the road while those at the back of the field spend up to 11 hours covering the same distance.

The climatic conditions are not favourable during the race, the majority of running being done in the heat of the day which is seldom below $20^{\circ}$ Centigrade. It was $28^{\circ} \mathrm{C}$ in 1986. As Noakes points out temperatures such as these are associated with a high risk of heat fatigue especially in less trained subjects. Coupled with this is the high incidence of dehydration ${ }^{2}$ which occurs during the race. The demands of this race cause new running injuries and/or aggravate previous training injuries.

During the Lond on marathon, physiotherapists were stationed half-way and at the end of the race. MacDonald $^{3}$ stated that physiotherapists were an essential

Linda Exelby, B.Sc. Physiotherapy

Formerly in private practice, but not currently working

\section{OPSOMMING}

Fisioterapie punte langs die Comrades Marathon roete het behandeling aan muskulo-skeletale probleme verskaf.

Die mees algemene spiertoestande wat voorgekom het, was uitputting, krampe en ooreising. Laasgenoemde toestande is met ysmassering, algemene masseringstegnieke of 'n kombinasie van die twee behandel. Elke deelnemer is ook aangemoedig om die beseerde spiere te strek. Beserings van gewrigsoorsprong is verbind. Vraelyste is aan die deelnemers gestuur om die effektiwiteit van die behandeling wat ontvang is, te bepaal. Die meeste deelnemers het geantwoord dat hulle baie baat daarby gevind het. Ten spyte van die beperkte beskikbare behandeling ontvang, het amper die helfte blywende verligting ondervind.

part of the medical team at the marathon. The majority of treatments appear to have been done after the finish of the race or on runners who were unable to continue because of injury. The Comrades Marathon, with its cut-off time of more than twice that of a standard marathon, differs in that more stations have to be situated along the course. This means that treatment duration is limited to the period during which the runner is prepared to stop - usually less than 5 minutes.

The major problems encountered by runners were identified during the 1985 race. These were muscular fatigue, cramp and the usual long distance tendon and joint injuries.

To establish the most effective treatment, the type, severity and extent of problems encountered, needed to be identified. In addition feedback from the competitors was needed to evaluate the effectiveness of our treatments.

\section{METHOD}

1. Six physiotherapy stations were established along the Comrades route approximately every $10 \mathrm{kms}$, from the $30 \mathrm{~km}$ mark onwards.

2. The treatment techniques chosen for muscular conditions (that is fatigue, cramp and strains) were ice 
massage, conventional massage or a combination of the two. Sustained stretching was encouraged, either during or after the treatment.

2.1 Ice massage was applied to the whole muscle using a circular motion. Water frozen in polystyrene cups was found to be the most practical and convenient way of providing cooling. ${ }^{4,5}$ Not only is ice less expensive than ethyl chloride but it is safer as it cannot reduce skin temperatures to dangerous levels. This form of treatment was chosen, as studies have shown that that skin and superficial muscle tissue temperatures can be decreased within 2 to 5 minutes in this way. ${ }^{6}$

2.2 The conventional massage technique used was palmar kneading to the whole muscle. Deeper finger massage was applied to areas of local spasm, without causing pain. No proprietary lotions of the wintergreen type were used as a cooling effect was desired.

2.3 Sustained stretching, repeated three times for ten seconds each, without producing pain was encouraged. This has shown to have a prolonged positive effect on muscle relaxation and flexibility. ${ }^{7,8,9}$

3. The second major group of conditions was joint related injuries. These were strapped with the consent of the runner. Knee and ankle strappings were standardized. ${ }^{10}$ The strapping material was Elastoplast elastic adhesive bandage, as recommended by manufacturers.

4. Other injuries encountered were treated at the physiotherapists' discretion, using any of the above mentioned modalities. In addition a supply of antiinflammatory cream was provided.

5. To ensure that treatments were carried out in as uniform a manner as possible, two workshops were held prior to the race, where all the above methods were practised.

6. At each station the runner's race number, his injury and treatment were recorded.

7. 800 of the runners who received treatment at our physiotherapy stations were sent a questionnaire within a week of running the race. 34 per cent of questionnaires were returned and analysed to establish the effectiveness of the treatments used.

\section{RESULTS}

1010 runners stopped at our stations. They represented 10 per cent of all runners registered as starting the race. 21 per cent of these runners were treated more than once. In addition to the six physiotherapy stations almost every watering station had people administering wintergreen based lotions. These treatments are not included in the figures quoted above. The majority (76 per cent) of runners treated at our stations took longer than nine hours to complete the race or did not finish (10 per cent). Half of these runners were novices.

38 per cent of runners started the race with injuries, however minor. Of these the more common injuries were: runners knee, pain localized around the lower border of the patella (12 per cent), iliotibial band syndrome ( 11 per cent) and muscular injuries (10 per cent).

Most stations treated 200 runners, with 2 stations each treating over 300 people. For this reason the conditions that were treated could only be recorded into broad categories of muscular and joint problems. Because strapping was applied to the iliotibial band syndrome and runner's knee, these have been classed as joint problems. In all, 1000 muscular treatments were performed and 243 joint problems attended to (Table 1).

Table 1.

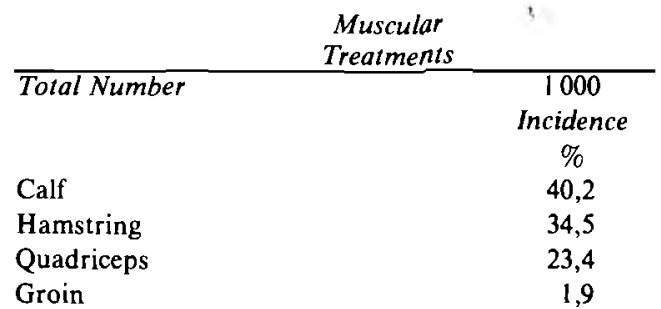

\begin{tabular}{|c|c|}
\hline & \\
\hline Total Number & $\begin{array}{c}243 \\
\text { Incidence } \\
\%\end{array}$ \\
\hline Left knee & 56,4 \\
\hline Right knee & 29,6 \\
\hline Ankles & 7,8 \\
\hline Other & 6,2 \\
\hline
\end{tabular}

Table 2. Muscular conditions

$\begin{array}{ccccc} & \% & \% & \% & \\ \text { Not } & \text { Effective } & \text { Effective } & \text { Total No. of } \\ \text { Effective } & 0-10 \text { mins. } & \text { more than 15 mins. } & \text { respondents } \\ \text { lce Massage } & 9 & 50 & 41 & 46 \\ \text { Massage } & 12 & 43 & 45 & 140 \\ \text { lce Massage } & 5 & 47 & 48 & 98 \\ \text { \& Massage } & & & & \end{array}$


Table 3. Joint conditions

\begin{tabular}{|c|c|c|c|c|c|c|}
\hline asing relief $\%$ & $\begin{array}{c}0-15 \text { mins } \\
17.5\end{array}$ & $\begin{array}{c}15-30 \text { mins } \\
14\end{array}$ & $\begin{array}{c}30-60 \text { mins } \\
14\end{array}$ & $\begin{array}{c}1-3 \text { hours } \\
24,5\end{array}$ & $\begin{array}{c}\text { Longer } \\
30\end{array}$ & $\begin{array}{l}\text { Total No. of } \\
\text { respondents } \\
57\end{array}$ \\
\hline & & & & & & \\
\hline
\end{tabular}

Having categorised the conditions which occurred during the race the effectiveness of treatment was assessed from the questionnaire responses.

Muscular conditions in the questionnaire were divided into fatigue and cramp. The results showed that all three treatment options gave similar effectiveness. 9l per cent of the runners perceived the treatment given to be effective. Runners were also asked for how long the treatment was effective (Table 2).

For joint conditions, 90 per cent of respondents perceived strapping to be effective. Most ( 89 per cent) of the strapping was done to the knee. Of this figure 71 per cent had had knee related injuries at some time during their training. A high percentage of these runners started the race injured as detailed above. 54 per cent of runners found strapping to be effective for longer than one hour. Some restrapping was however necessary. The effectiveness of the strapping is set out in Table 3.

\section{DISCUSSION}

The predominant muscular conditions were in the calf and hamstring muscle groups, similar to those found by MacDonald ${ }^{3}$ during the London Marathon. In a race such as Comrades, where the distance is longer, the terrain hilly and climatic conditions more severe, these problems were greatly increased.

The Pietermaritzburg to Durban race, that is the downhill run has a number of steep uphills in the first half of the race and thereafter downhill running predominates. Those finishing after 9 hours tend to cover the last part of the race by walking uphill and running downhill. Downhill running is an aggravating or causative factor in running injuries especially when the runner is fatigued. Studies have shown that the hamstrings, quadriceps and gluteal muscles in particular are affected in these cases. Steep uphill running is responsible for the calf and groin problems.

A high percentage of runners found the treatment effective. The treatment time varied between 1 and 3 minutes and it is doubtful that simply resting for this period would contribute to the relief of fatigue. In a race situation it is not possible to have a control who rests only, so for this reason we considered a muscular treatment to be effective if the effects lasted more than 15 minutes and indeed nearly half of the respondents reported this to be the case.

It is well established that high temperatures reduce muscle efficiency and increase fatigue especially in unacclimatized subjects. ${ }^{11,12,13,14}$ It was evident from the questionnaire that most runners fell into this category. Some 88 per cent trained in the cool of the day.
A combination of ice and conventional massage gave the most lasting relief by a small margin, so proving to be the most effective treatment.

With the short treatment duration of ice massage the cooling of the skin predominated over deep muscle cooling. ${ }^{6,15,16,17,18,19}$ Decreasing skin temperature allows blood which has pooled in the veins to return to the circulation. ${ }^{i}$ This cooled blood becomes available to the working muscles and increases their efficiency.

Massage is a well established treatment which mobilizes muscle tissue, reduces spasm and improves circulation to localized ischaemic areas. With massage one is able to identify the problem area by feel and so localize treatment to these areas. Muscle cramping is effectively treated with gentle massage and sustained stretching. ${ }^{3}$

Stretching, ice and conventional massage each has its own unique effect and obviously the combination of all three make for a more effective treatment.

Of the above results discussed there is no doubt of the importance of ice in the treatment of injury to muscles, tendons or joints. It is therefore a necessity at all long distance events. The area of application is small and a 3 minute ice massage will effectively reduce the activity of pain receptors and local inflammation. ${ }^{18}$

The most striking aspect of the strapped conditions was the high incidence of left knees requiring strapping. Sixty two per cent of runners reported that they had run in the middle or on both sides of the road equally during the race. Therefore it is doubtful that the race itself was the main cause of the high incidence of left knee injury.

It is common for entrants to train for 12 weeks or more at distances of a 100 or more $\mathrm{kms}$ a week. It is during these long distances that most injuries occur. This is borne out by the questionnaire results which show that 71 per cent of those knees strapped started the race injured or had been injured during their training. For safety reasons most training is done on the right hand side of the road and this is reflected by the high incidence of left knee injuries. This injury group consisted of mainly iliotibial band syndrome and runner's knee. Further research is needed to identify to what extent the degree of camber of the road causes injuries to occur more in one knee than in the other.

Myburgh's ${ }^{20}$ work has shown strapping loosens so that after one hour it no longer restricts normal joint movement. However, it is possible that the strapping's supportive and proprioceptive functions last longer. Taking this into account and the difficulties with getting strapping to stick on sweaty, hairy legs or those coated with greasy lotions, we are satisfied with the large number of runners who said their strapping lasted for 
longer than an hour. The introduction of an agent to remove greasy lotions in subsequent Comrades marathons should help to eliminate one of these problems.

\section{CONCLUSION}

We were able to show that physiotherapists form an essential part of the medical team during long distance races. The treatments offered were found to be effective for most musculoskeletal problems especially when one considers the short time available for treatment. From now on we plan to give lectures to the other First Aid stations along the route so they will be able to deal with muscle fatigue and cramp more effectively.

In spite of all the media coverage of road running and its associated injuries the large number of runners treated prove that further preventive education is needed. Physiotherapists should play a more active role in this facet of preventive medicine. Lectures and clinics should be held at the beginning of the season.

The Sports Interest Group of the Natal Coastal Branch offers this service to clubs. There is considerable scope for other physiotherapy branches to provide preventative education early in the season to the large dedicated following this sport commands.

\section{ACKNOWLEDGEMENTS}

The author would like to thank Smith and Nephew with whom we work closely. Also thanks go to J. Exelby for his assistance and J. Morton for help with compiling the questionnaire.

\section{References}

1. Noakes T. Lore of Running. Oxford University Press, 1985: 15-75, 271-304, 325-380.

2. Maughan RJ. Temperature regulation during marathon competition. Br J Sports Med 1984; 18(4): 257-260.

3. MacDonald R. Physiotherapy management of marathon musculo-skeletal casualties. Br J Sports Med 1986; 18(4): 283-285

4. McMaster WC, Liddle S and Waught TR. Laboratory evaluation of various cold therapy modalities. Am J Sports Med 1978; 6(5): 291-294.

5. Lowdon BJ and Moore RJ. Determinants and nature of intramuscular temperature changes during cold therapy. Am J Phys Med 1975; 54(5): 223-233

6. Waylonis GW. The physiologic effects of ice massage. Arch Phys Med Rehabil 1967; 48: 37-42.

7. Prentice WE. An electromyographic analysis of the effectiveness of heat or cold and stretching for inducing relaxation in injured muscle. Jospt 1982; 3(3); 133-140.

8. Siff MC. Flexibility in sport. SA Sports Med 1983; 19: 2-6.

9. De Vries H. Prevention of muscular distress after exercise. Res $Q$ 1960; 32(2): 177-185.

10. Elastosport. A Strap in Time. Smith and Nephew.

11. Fink WJ, Costill DL and Handel PJ. Leg muscle metabolism during exercise in the heat and cold. Europ $J$ Appl Physiol 1975; 34: 183-190.

12. Edward RHT, Harris RC, Hultman E et al. Effect of temperature on muscle energy metabolism and endurance during successive isometric contractions, sustained to fatigue, of the Quadriceps muscle in man. J Physiol 1972; 220: $335-352$.

13. Clarke DH and Stelmach GE. Muscular fatigue and recovery curve parameters at various temperatures. Res $Q$ 1965; 37(4): 468-479.

14. Petajan JH and Eagan CJ. Effect of temperature, exercise and physical fitness on the triceps surae reflex. $J \mathrm{Appl}$ Physiol 1968; 25(1): 16-20.

15. Bierman $W$ and Fridlaner $M$. The penetrative effect of cold. Arch Phys Med Rehabil 1940; 21: 585-592.

16. Barcroft $\mathrm{H}$ and Edholm $\mathrm{OG}$. The effect of temperature on blood flow and deep temperature in the human forearm. I Physiol 1943; 102: 5-20.

17. Kowal MA. Review of physiological effects of cryotherapy. Jospt $1983 ; 5(2)$ : 66-73.

18. De Jesus PV, Hausmanova-Petrusewiez I and Barchi $\mathrm{RL}$. The effect of cold on nerve conduction of slow and fast nerve fibres. Neurol 1973; 23: 1182-1189.

19. Lee JM and Warren MP. Cold Therapy in Rehabilitation. London: Bell and Hyman, 1978: 15-71.

20. Myburgh KH and Vaughn CL. Ankle guards and taping; do they really work? SA Sport Med 1986; 22: 4-6.

\section{Bibliography}

1. Barnes Jo M. Presenting research in a scientific article. $S A$ Journal of Physiotherapy 1986; 42(1): 10-15.

2. Sainsbury R. Medical experience of the Great North run. Br J Sports Med 1984; 18(4): 265-267.

\section{Try New Flotation Pads to keep you free from bedsores}

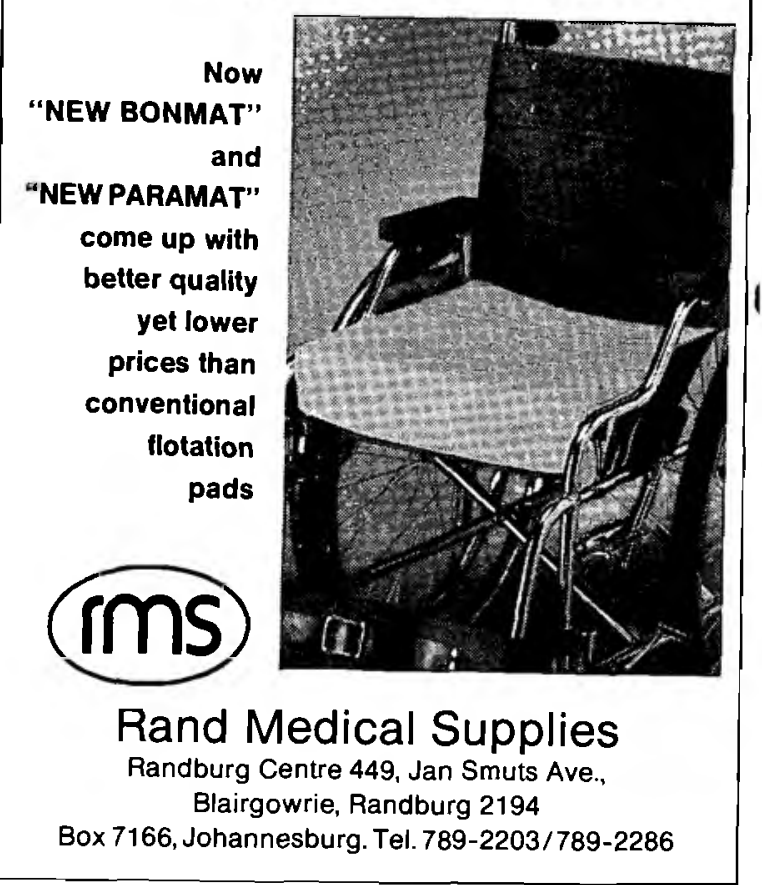

